\title{
Exploitation of Satellite Data for the Mapping of Areas at Risk of Flooding in Grand-Bassam (Côte d'Ivoire)
}

\author{
Kouakou Hervé Kouassi*, Zilé Alex Kouadio, Arthur Brice Konan-Waidhet, \\ Affessi Christian Serge Affessi, Kouakou Lazare Kouassi \\ Laboratory of Science and Technology of Environment, Jean Lorougnon Guédé University, Daloa, Côte d'Ivoire \\ Email: *kh.kouassi@gmail.com
}

How to cite this paper: Kouassi, K.H., Kouadio, Z.A., Konan-Waidhet, A.B., Affessi, A.C.S. and Kouassi, K.L. (2020) Exploitation of Satellite Data for the Mapping of Areas at Risk of Flooding in GrandBassam (Côte d'Ivoire). Advances in Remote Sensing, 9, 117-126.

https://doi.org/10.4236/ars.2020.94007

Received: October 24, 2020

Accepted: December 10, 2020

Published: December 30, 2020

Copyright (๑) 2020 by author(s) and Scientific Research Publishing Inc. This work is licensed under the Creative Commons Attribution International License (CC BY 4.0).

http://creativecommons.org/licenses/by/4.0/

\begin{abstract}
In order to better identify spatially the areas at risk of flooding for the riparian populations of Grand-Bassam during strong floods, a study aimed at developing hazard and vulnerability maps from RADAR Sentinel-1 and optical images Sentinel-2 has been put in place. The flood hazard study highlighted the flooded areas in Grand-Bassam. These areas represent 747.7 ha, or 1.02\% of the total surface. The vulnerability map produced using the maximum likelihood method identified eight (8) land use classes. These are the classes Water, Dense forest, Secondary forest, Swamp forest, Industrial crops, Food crops, Habitats and bare soils. It made it possible to highlight the socio-economic interests of Grand-Bassam. The flood risk map developed from the intersection of the themes of the vulnerability map and that of the hazard has enabled the recognition of risk areas which are located near the source of the risk (Comoé River) and at low altitudes. These are Moossou, Petit Paris, Quartier Phare and Quartier France.
\end{abstract}

\section{Keywords}

Remote Sensing, Hazard, Vulnerability, Flood Risk, Grand-Bassam

\section{Introduction}

Floods caused by floods are a common and recurring phenomenon in the history of mankind. Nevertheless, in recent years, these phenomena seem to be occurring at an accelerated rate and are becoming more devastating. Precise knowledge of these random phenomena is necessary for risk prevention [1]. In order to provide precise answers to the understanding of flooding problems, 
several studies have already been carried out around the world [2] [3] [4].

In Côte d'Ivoire, given the recurrence of these events, understanding and forecasting floods is an interesting means of flood risk prevention. However, flood forecasting through geographic information systems is currently very poorly developed, which leads to a lack of control over these phenomena in both urban and rural areas.

The coast of Côte d'Ivoire has many socio-economic interests. However, the recent floods observed undermine these interests. In fact, each year these floods cause considerable damage, namely the destruction of bridges, roads, habitats, plantations, etc.

Grand-Bassam, for its part, is faced with the phenomena of floods and floods linked to the repeated closure of the mouth of the Comoé River. These phenomena cause disasters and cause significant human and material damage. The example of the events of October 2019 is striking. Since Monday, October 14, the torrential rains which fell on the District of Abidjan and its suburbs caused flooding in several districts of Grand-Bassam including Azuretti, district France, Petit Paris, district Phare, Moossou and Ebrah, causing more than 5000 victims.

Geospatial technologies have their place in this management. Indeed, remote sensing provides many advantages. The acquisition of radar data is independent of weather conditions. These data have a greater ability to penetrate the natural environment. Several authors including [5] [6] use these data for flood mapping, respectively in the Moselle department (France) and in the San-Pédro region (Côte d'Ivoire).

Knowledge of hazards and flood risks is a fundamental prerequisite for their prevention. Hence the need for this study entitled: "Exploitation of satellite data for the mapping of areas at risk of flooding in Grand-Bassam (Côte d'Ivoire)".

\section{Materials and Methods}

\subsection{Study Area}

Grand-Bassam is located in the South East of the Ivory Coast bordering the Atlantic Ocean (Figure 1). It is located $36.2 \mathrm{~km}$ from Abidjan and its geographical coordinates are $05^{\circ} 14^{\prime}$ North latitude and $03^{\circ} 45^{\prime}$ West longitude. The locality of Grand-Bassam is the capital of the department of Grand-Bassam in the administrative region of southern Comoé. It includes three sub-prefectures which are Grand-Bassam, Bonoua and Bongo.

The Grand-Bassam area is drained by three rivers which are: the Comoé river and the Ebrié and Ouladine lagoons. These waters have crept into all the depressions, thus creating multiple arms. These rivers meet to form the largest estuary on the Ivorian coast at Grand-Bassam [7]. From a climatic point of view, the wetland is subject to an equatorial climate of transition with four alternating rainy and dry seasons. The great rainy season from April to June is interrupted by a short dry season from July to September. The long dry season lasts from December to March and is preceded by the short rainy season which lasts from 


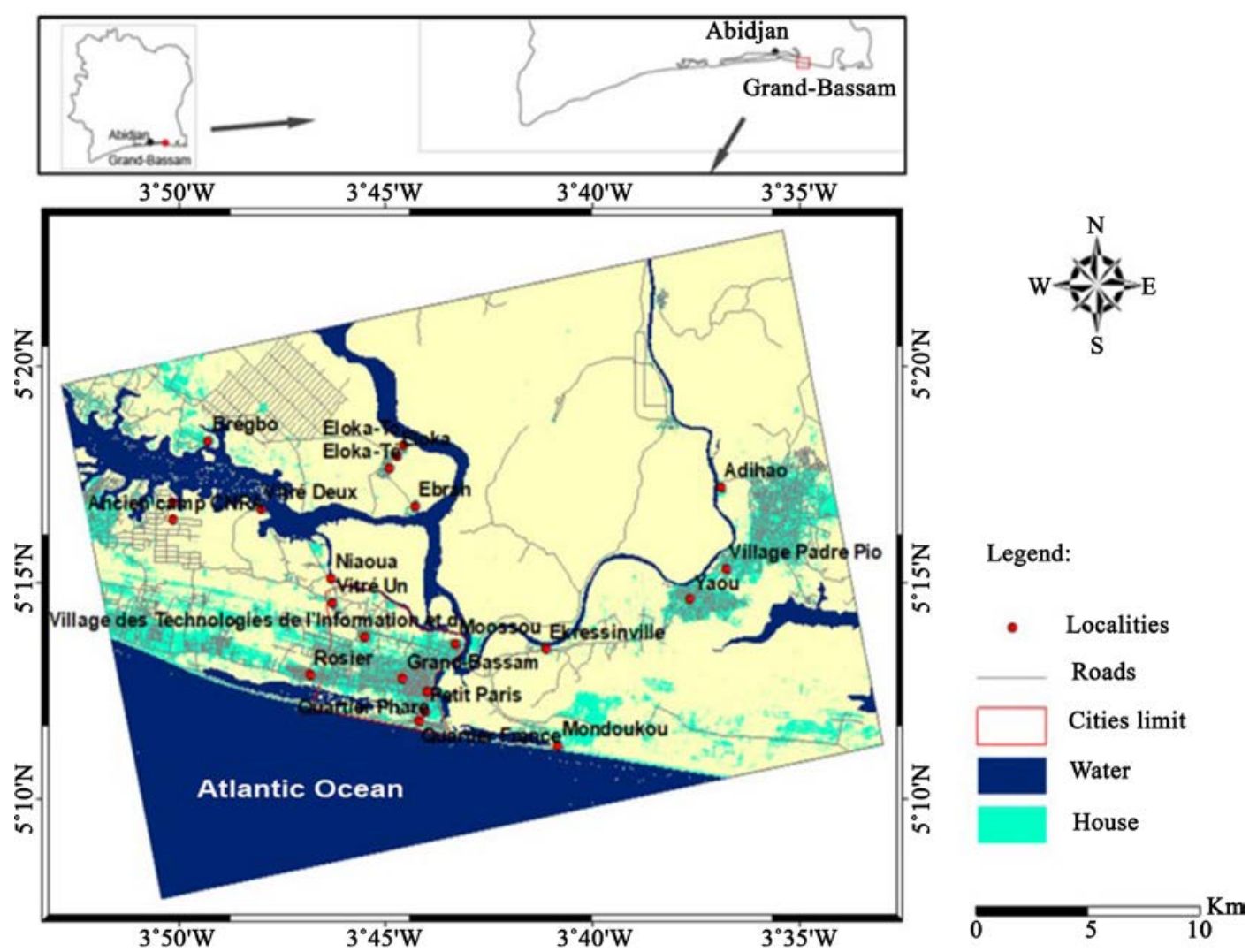

Figure 1. Geographical location of Grand-Bassam.

October to November. The coastal facies is very humid with an average annual rainfall exceeding $1500 \mathrm{~mm}$. The annual average temperature is $26.2^{\circ} \mathrm{C}$. GrandBassam is characterized by a plain whose altitudes rarely exceed $50 \mathrm{~m}$. The relief is made up of flat and sandy soil, more or less marshy lowlands with the presence in places of forest islands [6].

\subsection{Available Data}

To carry out this work, the data used mainly consists of remote sensing data. These are three Sentinel-1 RADAR images and one Sentinel-2 optical image. Regarding the Sentinel-1 RADAR data, we have, one (1) excluding floods and two (2) during the flood period. The characteristics of these images are presented in Table 1 and Table 2.

Sentinel-1 and Sentinel-2 data was provided by the Copernicus program's Sentinel data distribution platform with a policy of free and open data access to everyone with a guarantee of long-term continuity (https://scihub.copernicus.eu/dhus/\#/home).

\subsection{Methodology}

\subsubsection{Pre-Processing of "RADAR Data"}

\section{- Calibration}

Multilooking made it possible to have square pixels on the ground and to 
Table 1. Sentinel-1 RADAR data characteristics.

\begin{tabular}{cc}
\hline Polarization & VV/VH \\
\hline Band & $\mathrm{C}(\lambda=5.6 \mathrm{~cm})$ \\
Spatial resolution & $20 \times 22 \mathrm{~m}^{2}($ az. $\times$ gr. range $)$ \\
Pixel & $10 \times 10 \mathrm{~m}^{2}($ az. $\times$ gr. range $)$ \\
Mowing & $250 \mathrm{~km}$ \\
Index angle & $36^{\circ}-42^{\circ}$ \\
Format & GRDH \\
Acquisition date & $2019: 05,17,29$ October
\end{tabular}

Table 2. Sentinel-2 optical data characteristics.

\begin{tabular}{cc}
\hline Band & Multispectral \\
\hline Spatial resolution & $10 \mathrm{~m} ; 20 \mathrm{~m} ; 60 \mathrm{~m}$ \\
Revision time & 5 jours \\
Mowing & $290 \mathrm{~km}$ \\
Acquisition date & 2020: 05 January \\
\hline
\end{tabular}

reduce flickering. To carry out the multilookage, it is necessary to find the average pixel size along the Prange radar sight and to project it on the ground using the angle of incidence at the center of the scene $\theta_{C}$ according to Equation (1):

$$
P_{\text {range }}^{\text {sol }}=\frac{P_{\text {range }}}{\sin \left(\theta_{C}\right)}
$$

where, $P_{\text {range }}^{\text {sol }}$ the size of the pixel on the ground.

We then calculate the following ratio in order to know the number of lines to be averaged:

$$
R=\frac{P_{\text {range }}^{\text {sal }}}{P_{a z}}
$$

where: $P_{a z}$ : pixel size in azimuth. The number of views has been set to 5 views.

\section{- Terrain correction}

The use of SAR radar images in conjunction with other sources of information (optical images, GPS) requires that they be properly georeferenced. Georeferencing is an operation which consists in projecting images in the plane to make them conform to a projection system. Thus, all the images used were georeferenced in the WGS 84 geodetic system and in the UTM projection in zone 30 North.

\section{- Filtering}

RADAR images are subject to the effects of speckle, which makes them difficult to use without prior processing. The filter used for the removal of speckles is that proposed by [5]. The advantage of this filter lies in its ability to effectively reduce speckles in homogeneous and heterogeneous areas and to conserve both 
the spatial resolution and the reflectivity levels of targets or isolated heterogeneous structures [8]. This filter is one of the filters best suited to processing multipolarized SAR images [6] [9] [10].

\subsubsection{Flood Hazard Mapping}

It was possible to isolate the flood zones by simply thresholding the numerical values of the radar backscatter coefficient. Indeed, the thresholding of an image makes it possible in particular to identify and isolate certain values which identify objects which have the same spectral characteristics.

Pixels in flood zones have values less than $-15 \mathrm{~dB}$. All the pixels whose numerical value is lower than the threshold value of $-15 \mathrm{~dB}$ have to be assigned to the class "flood zones". This is also the case with [6], who used it to discriminate against flooded areas in the San-Pédro region (Côte d'Ivoire).

\subsubsection{Vulnerability Study}

The aim here is to highlight the threatened socio-economic issues. To do this, an image of Sentinel 2 is used to make the land use map. The coupling of the land use map with the field campaigns is carried out in order to map the threatened socio-economic issues, to quantify them and to highlight the sensitivity of the environment to the risk of flooding. Information on land use is obtained from classifications supervised by the maximum likelihood method [7]. Photo- interpretation of composite images from optical data, combined with aerial photographs and calculated indices, identified land cover classes. For a good appreciation of the landscape units, three classifications were made from the three colored compositions (true colors, infrared and atmospheric penetration).

\subsubsection{Estimate of the Flood Risk}

The flood risk takes into account the flood hazard and the vulnerability to flooding. The method used to obtain the risk is the direct application of its mathematical definition which results in the following formula [11]:

$$
R=A^{*} V
$$

with: $A$ : Alea; $R$ : Risk; $V$ : Vulnerability.

\section{Results}

\subsection{Mapping of Flooded Areas}

The histogram thresholding applied to the various Sentinel-1 RADAR images made it possible to highlight the flooded surfaces. Figure 2 illustrates the flood conditions of Grand-Bassam. The flooded areas represent 747.7 ha, or $1.02 \%$ of the total area for the $17^{\text {th }}$, and $101.8 \mathrm{ha}$, or $0.14 \%$ of the total area for the $29^{\text {th }}$.

We note that these flood hazard zones occur mainly near the Comoé River (Figure 2).

The superposition of the flooded areas on the relief map provides information on the areas favorable to flooding. Note that the flooded areas are located at the lowest altitudes; between 0 and $8.2 \mathrm{~m}$ altitude. 


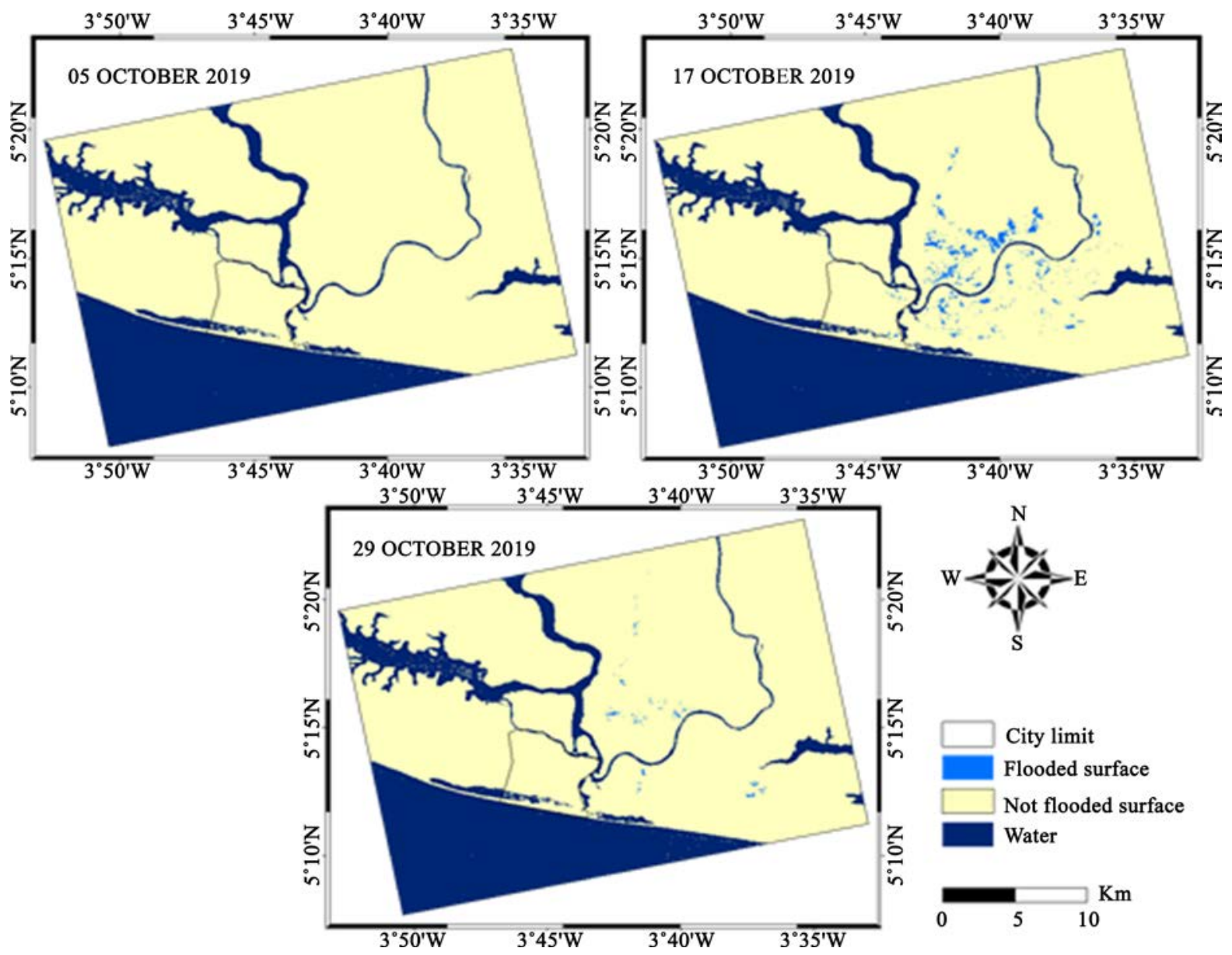

Figure 2. Maps of flooded areas obtained from RADAR Sentinel-1 satellite images.

\subsection{Vulnerability to Flooding}

Information on land use was obtained from classifications supervised by the maximum likelihood method. This method, carried out on the basis of photo-interpretation of satellite images coupled with field investigations, made it possible to produce the land use map essential for a good analysis of vulnerability to flooding (Figure 3). The land use map made it possible to highlight the socio-economic interests of Grand-Bassam.

From these results to determine land use, we determined eight classes. Floods affect populations and areas with socio-economic interests. This is highlighted through the flood risk map (Figure 4).

\section{Discussion}

The characterization of the flood hazard, carried out using the thresholding histogram method, made it possible to discriminate the flooded areas in Grand-Bassam. The results show that 747.7 ha of land were flooded on October 17, 2019 and 101.8 ha on October 29, 2019. This corresponds respectively to $1.02 \%$ and $0.14 \%$ of the studied area. These observed values, considered to be considerable, are the product of the abundant rains that fell during the month of 

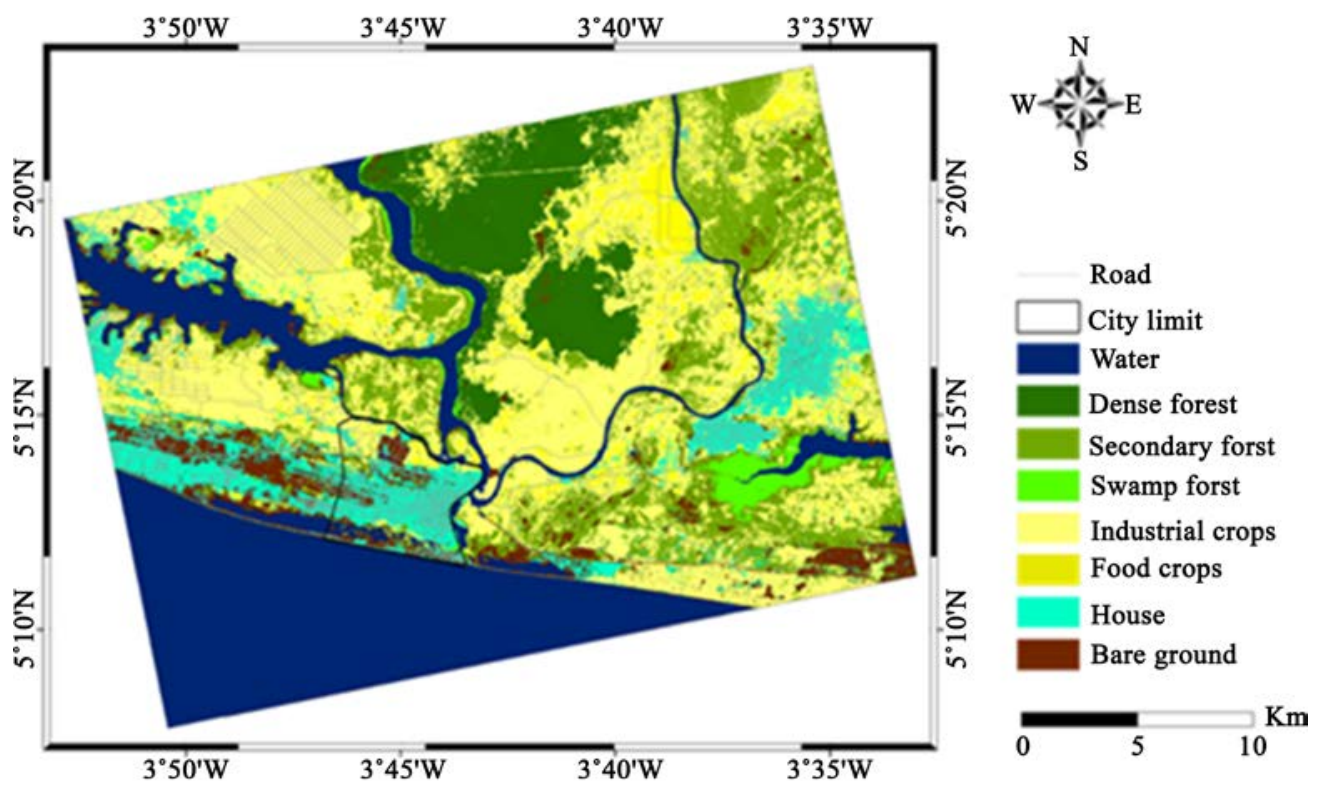

Figure 3. Land use in the study area.
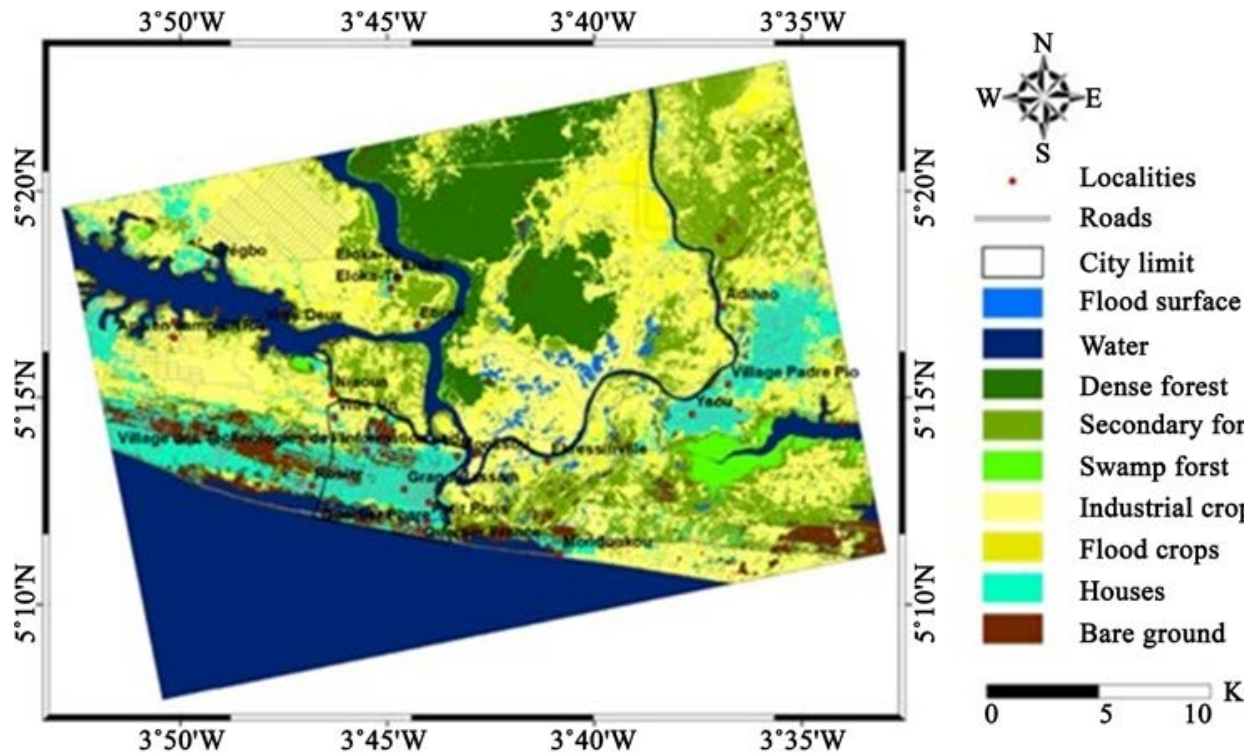

Dense forest

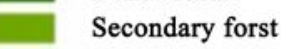

Swamp forst

Industrial crops

Flood crops

Houses

Bare ground

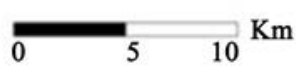

Figure 4. Map of areas at risk of flooding.

October 2020 in the locality of Grand-Bassam. Similar studies carried out by [6] in San-Pédro also showed heavy flooded areas. This region, characterized by abundant rains reaching $2000 \mathrm{~mm}$ per year, was the subject of a catastrophic event in July 2017. This study showed that 6007 ha of land had been inundated on June 16, 2017. In addition, the superposition of the flooded surfaces on the relief map showed that the floods occur in areas of low altitudes $(0-8.2) \mathrm{m}$. Indeed, the flat or slightly undulating relief of Grand-Bassam is not very conducive to good drainage of rainwater. It promotes diffuse runoff in these areas, which leads to rapid soil saturation. We are therefore witnessing flooding by runoff of accumulated rainwater. Moreover, according to [12], relief is an essential factor 
conditioning the flow of water on the ground surface. Low slope areas are in places submersible during the wettest months (June to September) of the rainy season in Man region.

In terms of vulnerability to flooding, the land use map produced using the maximum likelihood method identified eight (8) classes in the following proportions: Water 24\%, Dense forest $8 \%$, Secondary forest $16 \%$, Swamp forest $2 \%$, Industrial crops $34 \%$, Food crops $1 \%$; Habitats $10 \%$, Bare soils $5 \%$. Its analysis made it possible to recognize the issues on the ground vulnerable to flooding. These are areas of economic and social interest marked by the presence of habitats and industrial and food crops. These results are in the same field as those of [10], with differences in size linked to the different areas studied. In addition, the analysis of the land use reveals that the way of occupying the space accentuates the vulnerability to floods. Thus, the innumerable more or less regular real estate transactions create ecological conditions where rainwater can no longer penetrate into the ground. They therefore flow towards the lowest point, the mouth of the Comoé River. And, with the mouth closed, the water finds its place where it can, makes its bed as it wants. This is in agreement with the study carried out by [13] in Agboville which states that the way of occupying the land is an essential factor conditioning the submersion process. The people of Agboville prefer to occupy the lowlands which they consider favorable for petty trade and rice cultivation. However, by settling on these sites, they regularly obstruct the drainage paths of runoff water and therefore expose themselves to flooding. Regarding the spatialization of risk, the crossing between the vulnerability and hazard maps reveals that floods affect both areas of economic interest and populations. Thus, 560 ha of industrial crops and 80 ha of food crops are flooded on October 17, 2019; and, regarding habitats, 19 ha were flooded. The economic issues that have suffered considerable impacts are industrial crops representing $2.23 \%$ of the flooded area. As for Habitats, the results obtained are significant $(0.26 \%$ of the flooded area) insofar as these floods cause environmental degradation, material damage and social disturbances. This is corroborated by the work of [6] in the city of San-Pédro; these indicate that many socio-economic interests namely: port, industrial, residential, agricultural areas are damaged by the floods in this city.

\section{Conclusions}

In conclusion, this study, based on the RADAR and optical image processing phase, allowed a spatial characterization of the flood risk linked to the flood of October 14, 2019 in Grand-Bassam. The spatial characteristics obtained are the estimate of the extension of the water according to the relevance of the RADAR information and the classification of the types of land use in the flooded plain.

The spatialization of the water carried out by histogram thresholding applied to the Sentinel-1 RADAR images made it possible to discriminate the flooded areas. They are estimated at $747.7 \mathrm{ha}$, or $1.02 \%$ of the total area. The maximum 
likelihood method allowed us to know the distribution of land use and to assess the flooded areas. A total of eight (8) land use classes have been identified. These are the classes Water $24 \%$, Dense forest $8 \%$, Secondary forest $16 \%$, Swamp forest $2 \%$, Industrial crops $34 \%$, Food crops 1\%; Habitats 10\%, Bare soils $5 \%$.

The coupling of maps relating to the themes of hazard and vulnerability made it possible to identify areas at risk of flooding in Grand-Bassam. These areas are located at low altitudes and near the Comoé River. These areas are represented by Moossou, Petit Paris, Quartier Phare and Quartier France. A total of three (3) interest classes are exposed to the risk of flooding. These are the Habitats, Industrial crops and Food crops classes.

The results obtained show that the contribution of RADAR Sentinel-1 and Sentinel-2 optical data for flood mapping is significant.

However, a $2 \mathrm{D}$ numerical modeling would be interesting in non-permanent flow in order to predict the areas likely to be flooded and the maximum height of the water level in the event of overflow of the bed of the Sassandra river at San-Pédro.

\section{Conflicts of Interest}

The authors declare no conflicts of interest regarding the publication of this paper.

\section{References}

[1] Ngo, A.T. (2014) Evaluation environnementale du risque d'inondation dans le delta du fleuve Ha Thanh (Centre Viêt-Nam). Thèse de Doctorat, Université d'Orléans, Orléand, France.

[2] Kussul, N., Shelestov, A., Skakun, S., Li, G., Kussul, O. and Xie, J. (2014) ServiceOriented Infrastructure for Flood Mapping Using Optical and SAR Satellite Data. International Journal of Digital Earth, 7, 829-845. https://doi.org/10.1080/17538947.2013.781242

[3] Arusha, N. and Bharathi, B. (2019) Flood Detection and Flood Mapping Using Multi-Temporal Synthetic Aperture Radar and Optical Data. The Egyptian Journal of Remote Sensing and Space Science, 35, 1-56.

[4] Souissi, D., Zouhri, L., Hammami, S., Msaddek, M.H., Zghibi, A. and Dlala, M. (2020) GIS-Based MCDM-AHP Modeling for Flood Susceptibility Mapping of Arid Areas, Southeastern Tunisia. Geocarto International, 35, 991-1017. https://doi.org/10.1080/10106049.2019.1566405

[5] Hostache, R., Puech, C. and Raclot, D. (2007) Caractérisation spatiale de l'aléa inondation à partir d'images satellites RADAR. Geoprodigportail d Information Géographique, 381, 13 p. https://doi.org/10.4000/cybergeo.7722

[6] Kouassi, K.H., N'go, Y.A., Armand, A.K., Koua, T.J. and Stoleriu, C.C. (2020) Contribution of Sentinel 1 Radar Data to Flood Mapping in the San-Pédro River Basin (South-West Côte d'Ivoire). Asian Journal of Geographical Research, 3, 8 p. https://doi.org/10.9734/ajgr/2020/v3i230101

[7] Hauhouot, C. (2002) Les problèmes de l'aménagement de l'estuaire du fleuve Comoe à Grand-Bassam. Les Cahiers d Outre-Mer, 219, 307-324. https://doi.org/10.4000/com.1012 
[8] Lee, J.S., Jurkevich, T., Dewaele, P., Wambacq, P. and Oosterlinck, A. (1994) Speckle Filtering of Synthetic Aperture Radar Images: A Review. Remote Sensing Reviews, 8, 313-340. https://doi.org/10.1080/02757259409532206

[9] Kouakou, H.K., Yao, A.N., Vincent, T.A., David, N., Jacob, K., Issiaka, S. and Jean-Paul, R. (2011) Apport des images ALOS/PALSAR, ENVISAT/ASAR, et LANDSAT/TM à la cartographie des zones humides tropicales de Grand Lahou, Côte d'Ivoire. Photo-Interpretation European Journal of Applied of Remote Sensing, 47, 100-108.

[10] Kouassi, K.H. (2013) Caractérisation et cartographie des zones humides littorales par l'apport de données radar polarimétriques et optiques: Application aux zones de Sassandra, de Grand-Lahou et d'Abidjan (Côte d'Ivoire). Thèse de Doctorat, Université Nangui Abrogoua, Abidjan, Côte d'Ivoire, 179 p.

[11] Morin, M. (2008) Concepts de base en sécurité civile. Québec, Canada, 60 p.

[12] Saley, M.B., Kouamé, F.K., Penven, M.J. and Biémi, J. (2005) Cartographie des zones à risque d'inondation dans la région semi-montagneuse à l'Ouest de la Côte d'Ivoire: Apports des MNA et de l'imagerie satellitaire. Télédétection, 5, 53-57.

[13] Kouadio, Z.A., Soro, G.E., Kouakou, K.E., Goula, B.T.A. and Savané, I. (2018) Inondations fréquentes à Agboville (Côte d'Ivoire): Quelles origines? Larhyss Journal, 33, 189-207. 